\title{
Primeiro relato da ocorrência de Septoria musiva em álamo no Brasil
}

\author{
Álvaro Figueredo dos Santos ${ }^{1}$, Edilene Buturi Machado², Glen R. Stanosz ${ }^{3}$ \& Denise R. Smith ${ }^{3}$ \\ ${ }^{1}$ Embrapa Florestas, 84311-000, Colombo, PR, Brasil; ${ }^{2}$ Swedish Match do Brasil S.A., 80230-160, Curitiba, PR, Brasil; \\ ${ }^{3}$ Department of Forest Ecology and Management, University of Wisconsin, 1630 Linden Drive, Madison WI 53706, EUA
}

Autor para correspondência: Álvaro F. dos Santos, e-mail: alvaro@cnpf.embrapa.br

\section{RESUMO}

O fungo Septoria musiva foi isolado de plantas de álamo com sintomas de mancha foliar e cancro no caule, nos estados do Paraná e Santa Catarina, Brasil, em 2004. Testes de patogenicidade e subseqüente reisolamento de Septoria musiva confirmaram a hipótese de que este fungo era o agente causal da doença. Este é o primeiro relato de Septoria musiva em álamo no Brasil.

Palavras-chave: Populus sp., patologia florestal, Ascomycota.

\section{ABSTRACT}

First report of Septoria musiva in poplar in Brazil

The fungus Septoria musiva was isolated from infected poplar plants (Populus sp.) with symptoms of leaf spot and stem canker in Paraná and Santa Catarina States, Brazil, in 2004. Pathogenicity tests and subsequent re-isolation of Septoria musiva confirmed the hypothesis that this fungus was the causal agent of the disease. This is the first report of S. musiva on poplar in Brazil.

Keywords: Populus sp., forest pathology, Ascomycota.

O álamo, Populus deltoides, é uma espécie florestal plantada no Vale do Rio Iguaçu, nos Municípios de Porto União SC, Paula Freitas PR e União da Vitória PR, para uso na indústria de fósforos. Atualmente, a área plantada com álamo é estimada em 5000 ha. Há cerca de 13 anos observou-se a ocorrência severa da septoriose, causada por Septoria sp., nos viveiros e nos plantios adultos de álamo, causando manchas foliares e cancros em ramos (Figura $1 \mathrm{~A}-$ B) e troncos de árvores. No entanto, desconhece-se a espécie que ocorre nas plantações brasileiras. Assim, este trabalho teve o objetivo de avaliar as características morfológicas e moleculares de isolados de Septoria do álamo, visando a identificação da espécie.

Apenas os quatro isolados mais esporulantes de Septoria foram utilizados neste estudo e foram obtidos de folhas e ramos de plantas de álamo com lesões de septoriose, em plantios localizados em Porto União SC e Paula Freitas PR. Isolamentos em meio batata-dextrose-ágar foram feitos a partir de uma porção da massa conidial coletada de picnídios de folhas e ramos infectados com auxílio de uma agulha esterilizada, mantidos em câmara úmida por $48 \mathrm{~h}$, sob luz contínua. Prepararam-se também lâminas (azul de algodão + lactofenol) com uma porção da massa conidial coletada do material vegetal infectado, para observação das estruturas. Foi determinado o número de septos, o comprimento e a largura de 50 conídios para cada isolado, observada a morfologia dos mesmos e dos picnídios e das colônias. Os conídios provenientes das lesões tiveram seus comprimentos ligeiramente inferiores aos provenientes do meio de cultura. Os isolados de Septoria foram inoculados em folhas e caules de mudas.

Os conídios eram hialinos, cilíndricos, retos ou ligeiramente curvos, variando de um a quatro septos (Figura 1C). Os conídios apresentaram variação de dimensões de 19,8- 3,5 x 2,5-3,0 $\mu \mathrm{m}$, e foram produzidos em picnídios formados principalmente na superfície adaxial no centro das manchas foliares. As colônias de Septoria em meio de BDA apresentaram coloração cinza-claro a cinza-escuro, com pontos róseos, nas colônias esporulantes (Figura 1D). Todos os isolados foram patogênicos ao álamo.

A identidade dos isolados de álamo em estudo foi confirmada com base em comparações da morfologia do conídio e de colônias em relação a isolados conhecidos de $S$. musiva e também com base na análise de seqüências de DNA de um segmento da região ITS-5.8S do rDNA de aproximadamente 320 pares de bases. O segmento de rDNA foi amplificado por PCR e obteve-se a seqüência de DNA. As seqüências obtidas foram comparadas com seqüência de Septoria disponíveis no GenBank através do procedimento de Blast Search (http://www.ncbi.nlm. nig.gov.br) e tiveram seu depósito registrado sob o $\mathrm{n}^{\circ}$ GU130032. A análise molecular permitiu a identificação indireta e a confirmação da identificação morfológica dos isolados de álamo como pertencente à espécie Septoria 

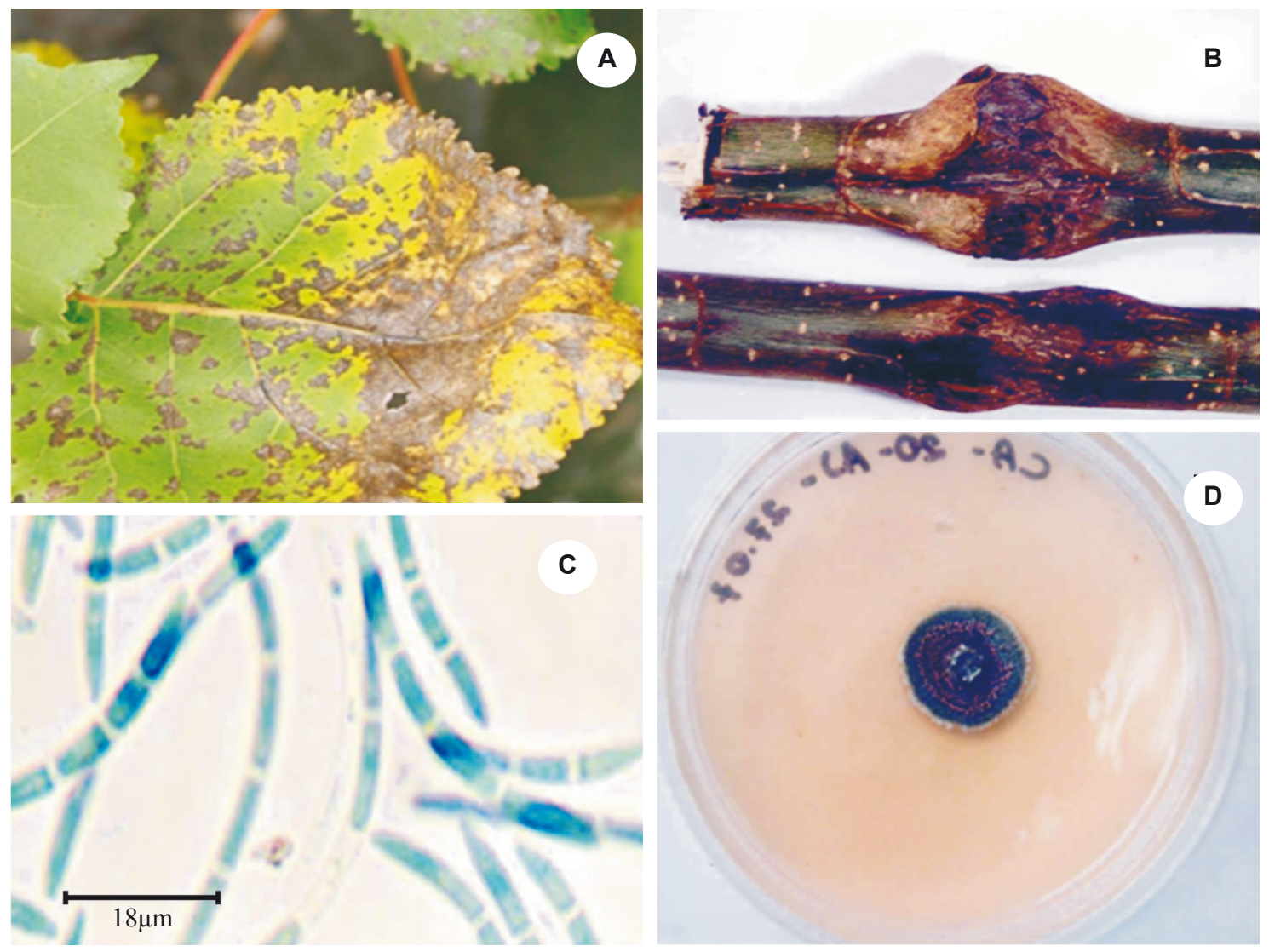

FIGURA 1 - Septoriose do álamo, causada por Septoria musiva. A. Lesões em folha; B. Cancro em ramos; C. Conídios; D. Colônia de S. musiva.

musiva Peck (Thompson, 1941; Feau et al., 2005; Filer et al., 1971; Feau \& Bernier, 2004). Não foi observado o teleomorfo Davidiella populorum (G.E. Thomps.) Aptroot em folhas ou ramos infectados, nem em cultura pura. Folhas sintomáticas foram herborizadas e depositadas no Museu Botânico Municipal, Curitiba PR, sob registro MBM 331810. A literatura registra a ocorrência de três espécies de Septoria no álamo (S. musiva Peck, S. populicola Peck e $S$. populi Desm.) na Europa, Ásia e América do Norte (Feau et al., 2005), embora no Brasil tenha sido constatado apenas S. musiva, constituindo-se este trabalho no primeiro relato deste patógeno em plantações brasileiras.

\section{REFERÊNCIAS BIBLIOGRÁFICAS}

Feau N, Bernier L (2004) First report of shining willow as a host plant for Septoria musiva. Plant Disease 88:770.

Feau N, Weiland JE, Stanosz GR, Bernier L (2005) Specific and sensitive PCR-based detection of Septoria musiva, S. populicola and S. populi, the causes of leaf spot and stem canker on poplars. Mycological Research 109:1015-1028.

Filer TH, McCracken FI, Mohn CA, Randall WK (1971) Septoria canker on nursery stock of Populus deltoides. Plant Disease Reporter 55:460-463.

Thompson GE (1941) Leaf-spot diseases of poplars caused by Septoria musiva and S. populicola. Phytopathology 31:241-254.

TPP9087 - Recebido 30 Junho 2009 - Aceito 19 Janeiro 2010 Editor de Seção: Eduardo S.G. Mizubuti 